\title{
CATASTROPHES CAUSED BY CORROSION
}

\author{
Zoran C. Petrović \\ Serbian Armed Forces, AF and AD, 204th Aviation Brigade, \\ Batajnica, Republic of Serbia \\ e-mail: pzoran.pele@gmail.com \\ ORCID iD: (ib)http://orcid.org/0000-0001-8053-4034
}

DOI: 10.5937/vojtehg64-10388

FIELD: Materials, Chemical Technology ARTICLE TYPE: Review Paper ARTICLE LANGUAGE: English

\section{Summary:}

For many years, huge attention has been paid to the problem of corrosion damage and destruction of metallic materials. Experience shows that failures due to corrosion problems are very important, and statistics at the world level shows that the damage resulting from the effects of various forms of corrosion is substantial and that, for example, in industrialized countries it reaches $4-5 \%$ of national incomes. Significant funds are determined annually for the prevention and control of corrosion. In the case of ignoring the problem of corrosion, in some cases the penalty is financial, whereas in other cases it is the loss of human lives.

This review presents several cases of failures in engineering structures and installations of catastrophic proportions, where corrosion was responsible for the occurrence of failures and the loss of hundreds of lives.

Key words: catastrophe, failure, corrosion, corrosion pit, pesticide, explosion, pipeline, helicopter, aircraft.

\section{Introduction}

Failures occur when a component or a structure is no longer able to withstand stresses imposed during exploitation. Usually, failures are related to stress concentration and they can occur for many reasons, including structural faults such as holes, notches and transitional curvatures of small diameters, cavities in the microstructure of materials as well as corrosive attacks, such as pitting, which generate local stress concentrations. 
Based on the research and statistical data, it is possible to estimate the frequency of failure mechanisms (Table 1). It is evident that corrosion, in all its forms (general corrosion, pitting corrosion, corrosion in the gaps, stress corrosion cracking, corrosion fatigue), dominates with $42 \%$ when it comes to the frequency of failure mechanisms in engineering structures. Also, in aircraft structures, where the largest number of failures is a result of fatigue, corrosion is the cause of even a quarter of the total number of failures (Findlay, Harrison, 2002).

Table 1 - Frequency of failure mechanisms

Таблица 1 - Частота механизмов отказов

Tabela 1 - Učestalost pojave mehanizama otkaza

\begin{tabular}{|l|c|c|}
\hline \multirow{2}{*}{ Failure mechanisms } & \multicolumn{2}{c|}{ Percentage of Failures } \\
\cline { 2 - 3 } & $\begin{array}{c}\text { Engineering } \\
\text { Components }\end{array}$ & $\begin{array}{c}\text { Aircraft } \\
\text { Components }\end{array}$ \\
\hline Corrosion & $\mathbf{2 9}$ & $\mathbf{1 6}$ \\
\hline Fatigue & 25 & 55 \\
\hline Brittle fracture & 16 & - \\
\hline Overload & 11 & 14 \\
\hline High temperature corrosion & 7 & $\mathbf{2}$ \\
\hline SCC/Corrosion fatigue & $\mathbf{6}$ & $\mathbf{7}$ \\
\hline Creep & 3 & - \\
\hline Wear/abrasion/erosion & 3 & 6 \\
\hline
\end{tabular}

Table 2 presents a few accidents caused by corrosion.

Table 2 - Overview of several characteristic accidents caused by corrosion

Таблица 2 - Обзор нескольких характерных несчастных случаев, вызванных коррозией Tabela 2 - Pregled nekoliko karakterističnih nesreća prouzrokovanih korozijom

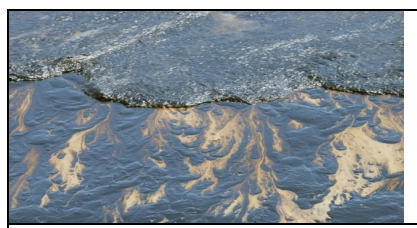

\section{5/19/2015 Oil spills (Santa Barbara / California)}

On one of the most biologically diverse coastlines in the United States, there was a discharge of $540 \mathrm{~m}^{3}$ of crude oil. Investigations indicated the presence of serious corrosion. In the lower quadrant of the pipeline, the thickness of which was reduced by $45 \%$ due to corrosion, there was crack propagation.

11/17/2014 The fall of railway traffic lights (Newbury I England)

A train traveling at $180 \mathrm{~km} / \mathrm{h}$ crashed into a railway traffic light that fell over two tracks. Corrosion caused almost a complete loss of the wall of the hollow pylon.

08/15/2014 Landing of a Jetstream away from the runway
(England)
Immediately after landing, the left leg of the landing gear
separated from the shackles. The aircraft slid off the runway into
the grass. The results of the investigation showed that the failure
had been caused by stress corrosion.

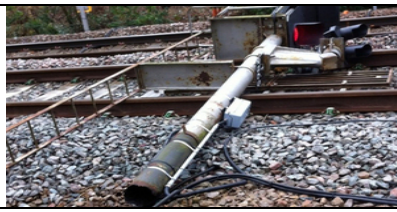
(England) 


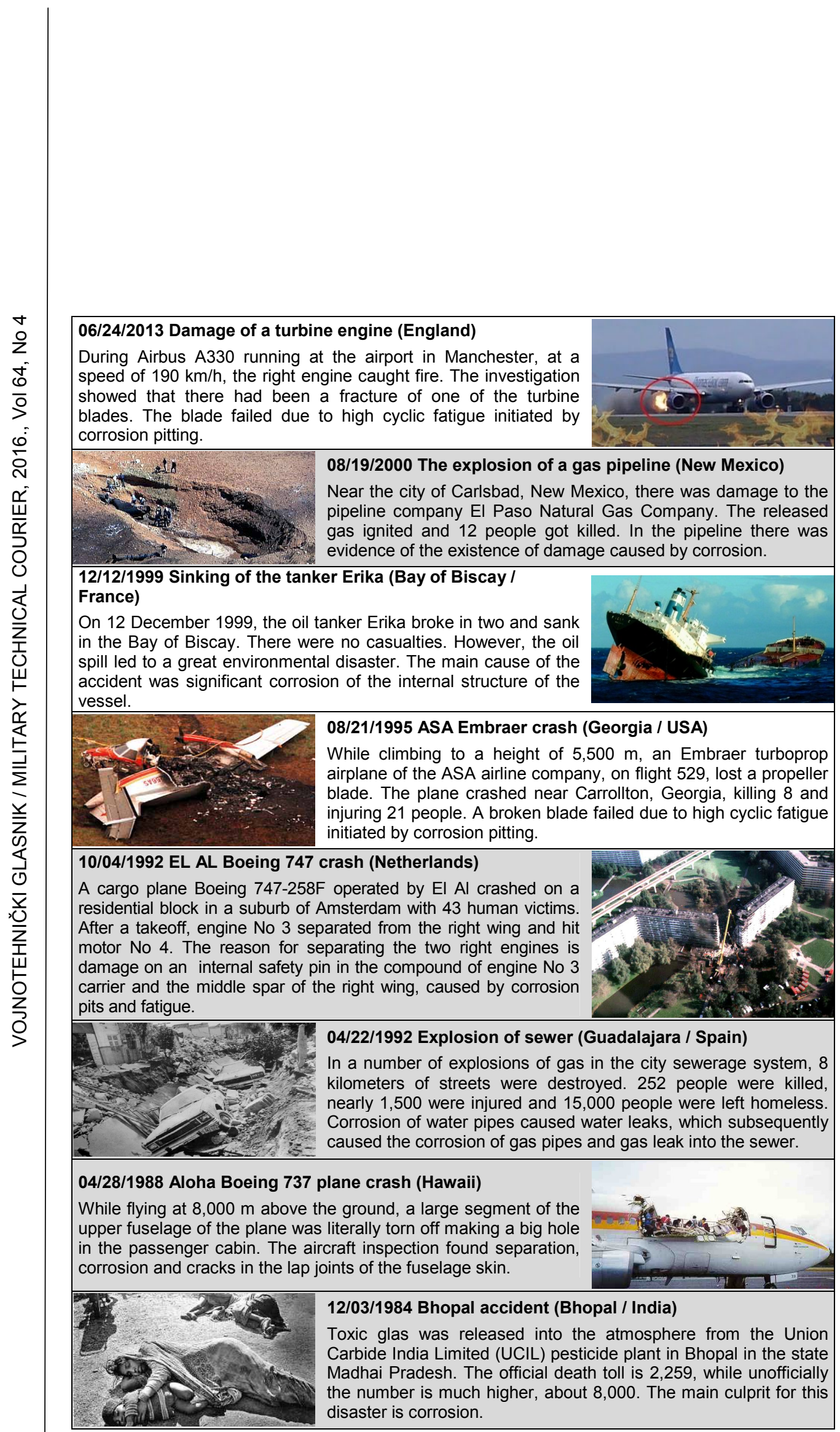




\section{5/10/1974 Sikorsky S-61N helicopter crash (North Sea)}

In May 1974, a helicopter Sikorsky S-61N PH-NZD crashed into the North Sea, where six people were killed. A fractographic analysis of blade No 3 found that the blades broke due to high cyclic fatigue initiated by corrosive pitting.
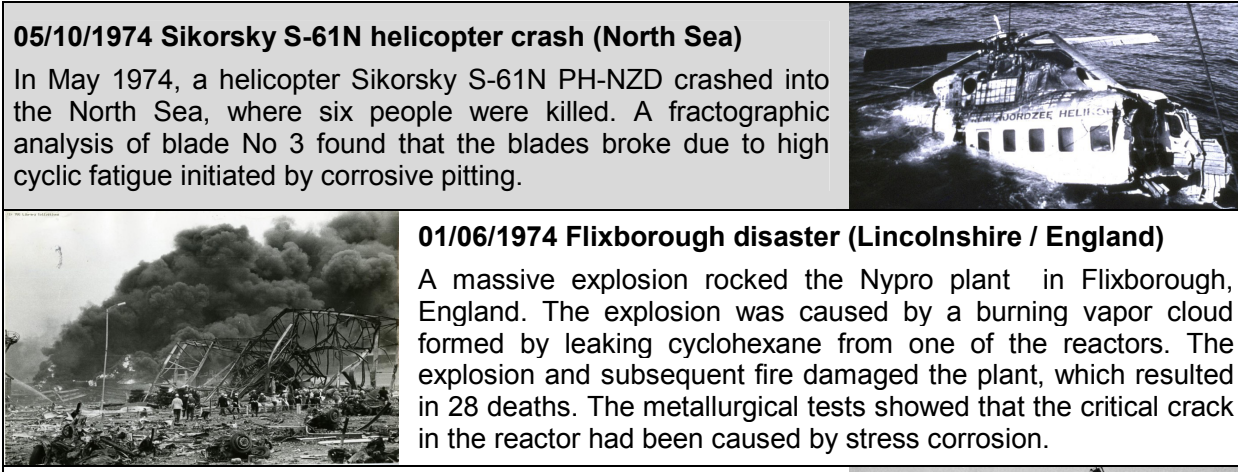

01/06/1974 Flixborough disaster (Lincolnshire / England)

A massive explosion rocked the Nypro plant in Flixborough, England. The explosion was caused by a burning vapor cloud formed by leaking cyclohexane from one of the reactors. The explosion and subsequent fire damaged the plant, which resulted in 28 deaths. The metallurgical tests showed that the critical crack in the reactor had been caused by stress corrosion.

12/15/1967 Demolition of the Silver Bridge (Ohio river / USA)

Point Pleasant bridge that connects West Virginia and Ohio, known as the Silver Bridge, collapsed on 15 December 1967. The accident resulted in 46 fatalities and 11 serious injuries. The disaster was caused by stress corrosion of the compound of the bridge construction and the bridge chain.

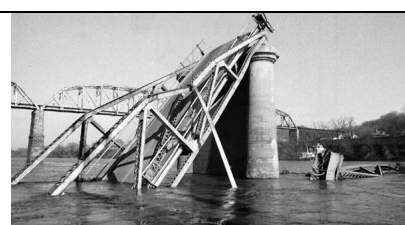

The article further presents in detail several catastrophic accidents, in which corrosion was responsible for the occurrence of failure and losses of human lives, from one to several thousand lives.

\section{Aloha Boeing 737 plane crash}

Structural damage to the plating on the Boeing 737 aircraft, operated by the US airline Aloha Airlines, which took place on 28 April 1988, undoubtedly contributed to the creation of awareness of aircraft aging. This aircraft suffered very serious damage caused by explosive decompression during flight. At $8,000 \mathrm{~m}$ above the ground, a large segment of the upper fuselage was literally torn off and it made a big hole in the passenger cabin (Miller, 1990).

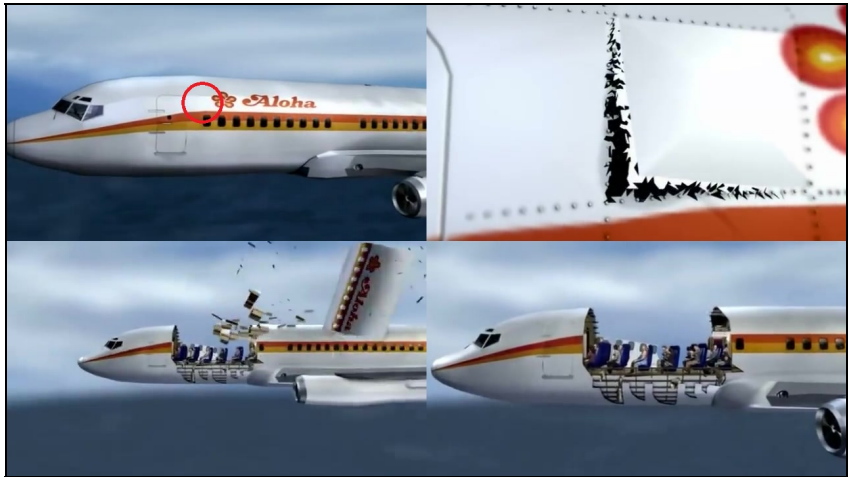

Figure 1 - Simulation of the flight of an airplane Boeing 737 Aloha Airlines, Flight 243

Puc. 1 - Моделирование полета самолета Boeing 737 Aloha Airlines Flight 243

Slika 1 - Simulacija leta aviona Boeing 737 Aloha Airlines Flight 243 
The crew landed the plane safely on the island of Maui in Hawaii. One flight attendant got killed, while 65 out of 94 survivors were injured. In the remaining structure of the aircraft, in several lap joints of the fuselage skin, in the holes of the upper row of fasteners, subsequent investigations discovered more cracks caused by fatigue (Wildey, 1990).

In the skin of the Aloha Boeing 737 aircraft, multiple damage was found in the form of cracks caused by fatigue which had led to the final structural damage. The report of the National Committee for Traffic Safety, made after the completion of the investigation in 1989, attributed the responsibility for the incident to the program of maintenance and detection of damage from corrosion. Earlier, in 1981, a similar plane suffered an in-flight break-up with more than one hundred fatalities. Investigations have indicated the existence of damage mechanisms to the fuselage skin panels caused by fatigue assisted by corrosion (http://www.corrosion-doctors.org/Aircraft/Aloha.htm).

Lap joints join large panels of the fuselage skin together and run longitudinally along the fuselage. Fatigue cracking was not anticipated to be a problem, provided the overlapping panels remained strongly bonded together. A review of other similar aircraft discovered separation, corrosion and cracks in the lap joints.

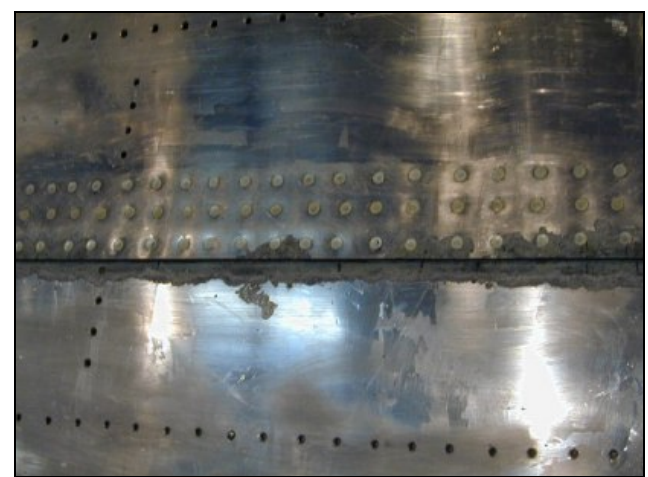

Figure 2 - Fuselage skin of the Boeing 737 Aloha

Puc. 2 - Обшивка фюзеляжа самолета Boeing 737 Aloha Slika 2 - Oplata trupa aviona Boeing 737 Aloha

Figure 2 clearly shows that the corrosion process and subsequent extensive accumulation of corrosion products within the lap joints led to the creation of so-called "pillowing", which finally led to the separation of the contact surfaces and uplifted the fuselage skin panels above the surface of the rivet heads (Komorowski, 1996).

This accident drew attention of aviation inspectors to airplanes of somewhat older age. The Aloha plane had flown for 19 years in a very 
unfavorable environment which is favorable for corrosion, typical for interislands aircraft. With an average flight duration of 20 to 40 minutes, the plane had 88,000 take-off-landing cycles.

\section{El Al Boeing 747 crash}

In October 1992, an El Al Boeing 747-258F cargo plane crashed on an apartment block in a suburb of Amsterdam with the loss of 43 lives and many injured.

About five minutes after the take off, engine No 3 and its pylon separated from the right wing in an outboard and rearward direction. Engine No 3 hit engine No 4, causing this engine and its pylon also to separate from the wing. Both engines and pylons fell into a lake about $25 \mathrm{~km}$ of Schiphol. During the engine separations, the wing leading edge was extensively damaged. This damage and loss of the two engines made control of the aircraft extremely difficult. An attempt was made to return to Schiphol, but tragically to no avail.

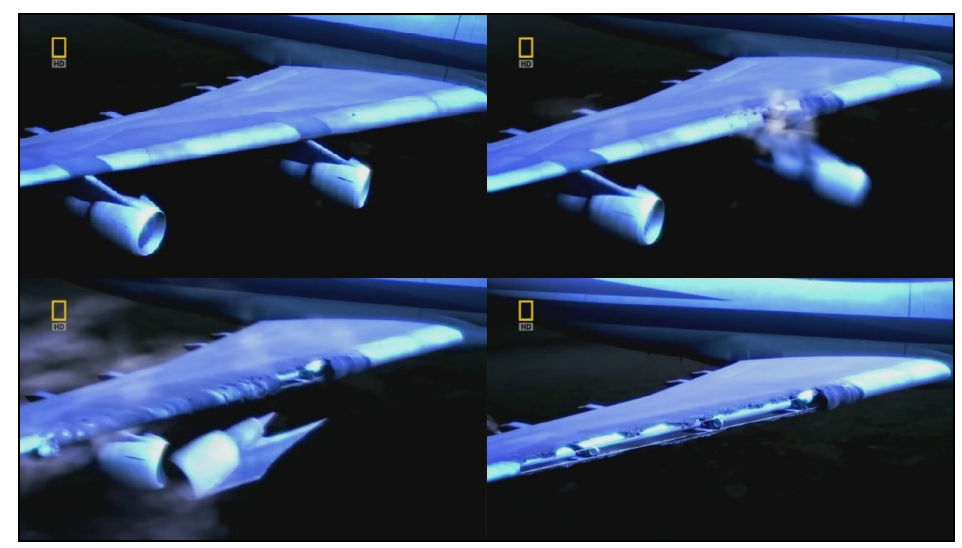

Figure 3 - Simulation of the El Al Flight 1862 crash in Amsterdam

Puc. 3 - Моделирование аварии самолета El Al Flight 1862 в Амстердаме Slika 3 - Simulacija udesa aviona na letu 1862 avio-kompanije El Al u Amsterdamu

The investigation of the accident involved a variety of organizations, including manufacturers of aircraft and engines, the operator of the aircraft, airtraffic authorities, the National Aerospace Laboratory - NLR from Amsterdam, etc.

The NLR's Department of Structures and Materials was responsible for investigating the components connecting engine No 3 pylon on the right wing. It turned out that these components were the key to explaining this complicated accident (Wanhill, 2009). 
A possible reason for the shearing away of the two right engines is damage to an internal safety pin of the mid spar (Figure 4) caused by corrosion pits and fatigue.

Pitting corrosion is defined as an extremely localized corrosion attack leading to the formation of corrosion holes (pits). Very small (limited) metal surfaces are subject to pitting corrosion, while the rest of the surface is in a stable, passive state, which leads to the creation of damage - spots, holes, pits, and craters. Pits are formed in the places of destruction of passive films on metal surfaces.

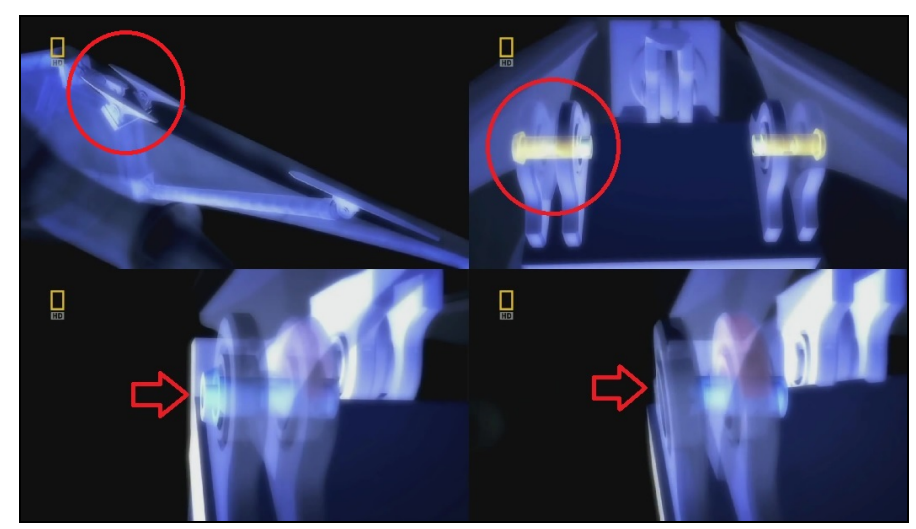

Figure 4-Internal safety pin of the mid spar

Puc. 4 - Внутренний предохранительный штифт среднего лонжерона Slika 4 - Unutrašna sigurnosna osovinica srednje ramenjače

The inboard and outboard pylon fittings and the partial fuse pin were made of AISI 4330M low alloy steel. The inboard pylon fittings were made of high strength steel $1517-1655 \mathrm{MPa}$, and the safety pin was made of medium strength steel $869-958 \mathrm{MPa}$. This design of the fuse pin had been used from 1982 and in a seven year period there were fifteen reports of cracked pins (http://www. corrosion-doctors.org/Aircraft/el-al.htm).

After this accident, Boeing introduced several changes for the pylonto-wing connections, including a newly designed safety pin made of corrosion-resistant stainless steel.

\section{Sikorsky S-61N helicopter crash}

In May 1974, the helicopter Sikorsky S-61N PH-NZD crashed into the North Sea, and six people were killed. Figure 5 shows the crashed helicopter during its recovery from the water. All the main rotor blades were broken, but blade No. 3 was an exception because of low deformation at the fracture (indicated in Figure 5). 


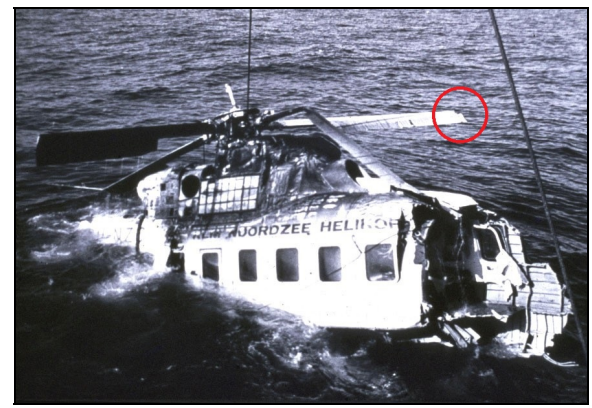

Figure 5 - Recovery of the helicopter Sikorsky S-61N PH-NZD from the North Sea

Puc. 5 - Извлечение вертолета Sikorsky S-61N PH-NZD из Северного моря

Slika 5 - Spasavanje helikoptera Sikorsky S-61N PH-NZD iz Severnog mora

Figure 6 shows a cleaned fracture surface of the blade spar No.3, made of aluminum alloy AA6061-T6. The spar is adhesively bonded to the sheeting in the form of a ribbed aluminum pocket, as shown in Figure $6 \mathrm{~b}$. The fractographic analysis determined the phases of the spar fracture and their order. The first phase was high-cycle fatigue initiated by corrosion pits on the spar lower surface under the bonded area (indicated by the red arrow in Figure 6b) (Wanhill, 2009).

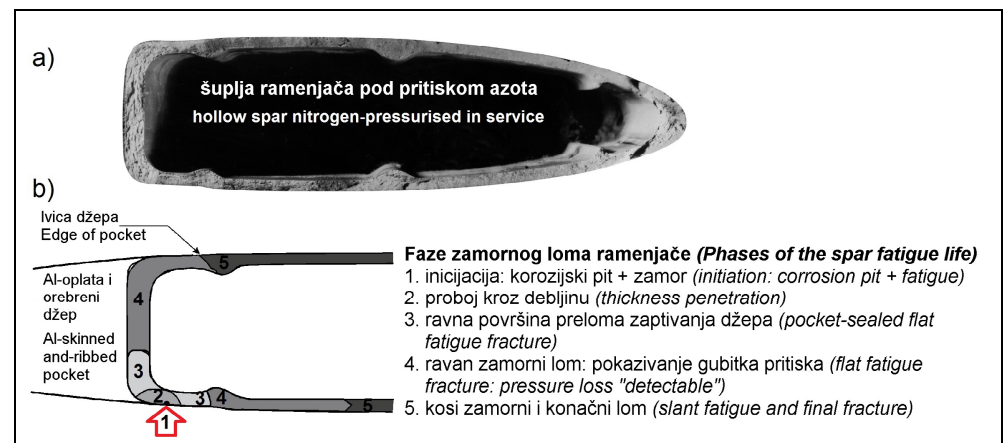

Figure 6 - Recovered blade spar fracture surface and the phases of the fatigue life Puc. 6 - Поврежденная поверхность лонжерена лопасти и фазы усталости Slika 6 - Oštećena površina preloma ramenjače lopatice i faze zamornog loma

\section{Bhopal accident}

Bhopal is probably the biggest industrial disaster in history. In the period between 1977 and 1984, the Union Carbide India Limited (UCIL) pesticide plant, located at a distance of 5-6 kilometers from the center of Bhopal, the state of Madhai Pradesh, was producing phosgene, monomethyl amine (MMA) methyl isocyanate (MIC) and the pesticide carbaryl, known as Sevin (http://www.corrosion-doctors.org/Pollution/ bhopal.htm).

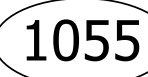


In the night between 2 and 3 December 1984, there was a penetration of large amounts of water into the tank with methyl isocyanate (MIC), with over 40 tons of MIC. The addition of water into the tank caused a runaway chemical reaction, resulting in a rapid rise in pressure and temperature. Heat generated by the reaction, chloroform concentrations higher than normal and the presence of an iron catalyst caused by the corrosion of the stainless steel tank wall, resulted in the opening of the safety valve. Toxic gas composed of MIC, hydrogen cyanide, monomethyl amine, carbon monoxide and other chemicals was released into the atmosphere. The wind blew the cloud of gas and more than 500,000 people were exposed to toxic effects of its ingredients. The parts of the town with dilapidated houses surrounding the plant were most affected, and the victims were exclusively from poor communities. The official death toll is 2,259 , while unofficially the number is much higher, about 8,000.

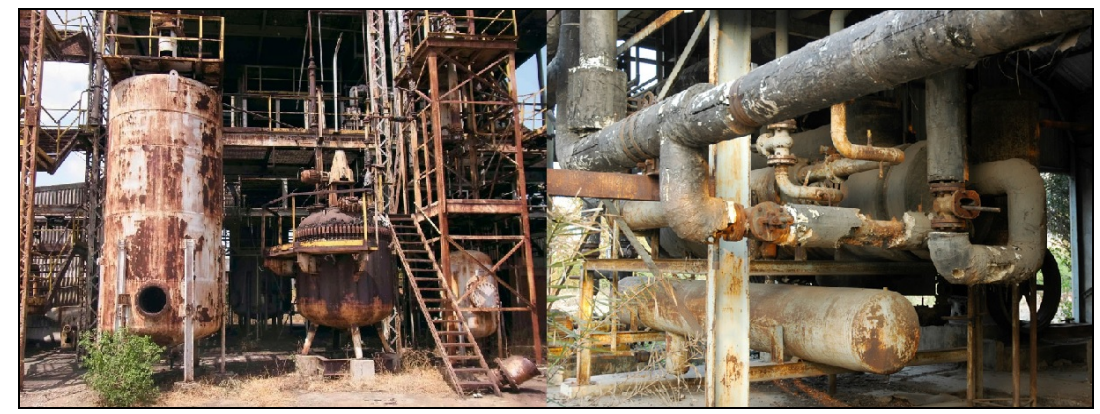

Figure 7 - Elements of the UCIL pesticide plant in Bhopal Puc. 7 - Завод по производству пестицидов UCIL в Бхопале Slika 7 - Elementi postrojenja za proizvodnju pesticida UCIL u Bopalu

As already mentioned, the immediate cause of the chemical reaction was the rush of 500 liters of water into the MIC storage tank. Many researchers and scientists have agreed that the corrosion of the pipelines and other safety equipment are the main culprit for this disaster. The following facts support this statement (Nitin, nd):

- MIC was stored in three double-walled stainless steel tanks, codenamed 610,611 and 619 . One of the third shift workers noticed that the pressure in tank 610 (the tank from which all MIC leaked) increased from 2 psi as it had been recorded one hour before, in the previous shift, to about $10 \mathrm{psi}$. Pressure increase for more than five times in an hour was not taken seriously because of the belief that the instrument for measuring pressure was faulty. Shakil Qureshi, the supervisor on duty, said later: "The instruments were often not working. They were corroded." 
- How water entered the pipeline connected to the MIC tank made of stainless steel is a different story, but its entry inside the tank was related to improper maintenance of the valve between the pipeline and the tank. In this case, the valves were made of carbon steel which easily corrodes in acidic media, which actually happened in the factory. In addition, sliding back panels, which should have prevented the entry of water through faulty valves had not been installed.

- The exact sequence of events in the tank remained unexplained. The Carbide's report states that what happened was a unique combination of large amounts of water (120 to 240 gallons), chloroform in an amount greater than normal (a few percent instead of the maximum of $0.5 \%$ ) and an iron catalyst, which led to a violent reaction in the MIC. The heat released by the reaction of water and MIC raised the temperature in the tank. At the same time, the reaction was accelerated by iron as a catalyst, resulting from the corrosion of the tank wall under the influence of high temperatures. The UCIL claimed that the corrosion rate was significantly increased due to the presence of an incredibly high level of chloroform. The rapid release of carbon dioxide in large quantities then helped to build up high pressures, which forced the foaming mass of chemicals out of the tank.

- The final blow was the fact that the tower designed to burn MIC was not usable due to the corrosion of a pipe which had not been replaced.

\section{The explosion of a gas pipeline}

On August 19, 2000, a $76 \mathrm{~cm}$ diameter natural gas transmission pipeline operated by the El Paso Natural Gas Company (EPNG) ruptured adjacent to the Pecos River near Carlsbad, New Mexico. The released gas ignited and burned for 55 minutes. Twelve persons who were camping under a concrete-decked steel bridge that supported the pipeline across the river were killed and their three vehicles destroyed. Two nearby steel suspension bridges for the pipeline crossing over the river were quite damaged. According to the EPNG, the damage amounted to \$998,296.

The force of the rupture and the violent ignition of the escaping gas created a crater 16 meters wide and blew out three large pieces of the pipeline. All three ejected pieces showed evidence of internal corrosion damage, but one of the pieces showed significantly more corrosion damage than the other two. Corrosion pits were visible on the inside surface of this piece, and the pipeline wall was significantly thinned at several locations. A perforation of the wall was visible at one location. No significant corrosion damage was visible on the outside surfaces of the three pieces or on the two ends of the pipeline remaining in the crater (National Transportation Safety Board, 2003). 


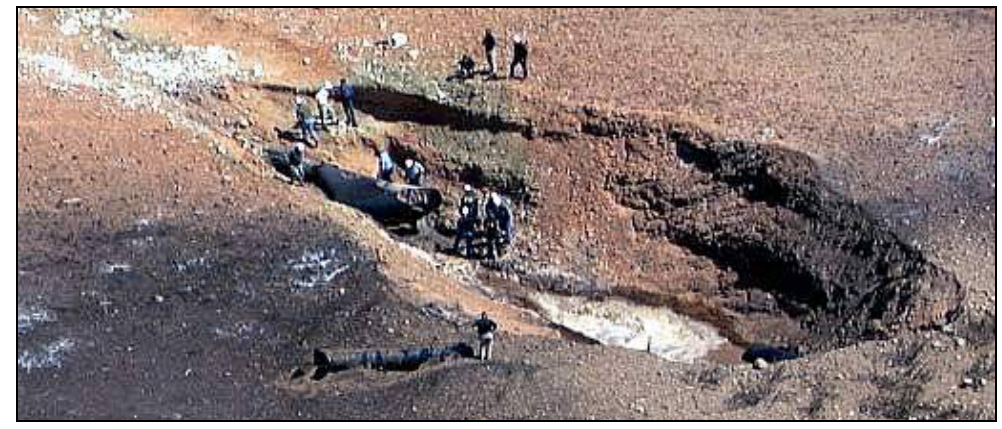

Figure 8 - The crater that was created in the explosion Puc. 8 - Кратер, образованный в результате взрыва Slika 8 - Krater koji je nastao prilikom eksplozije

Interconnecting pits were observed on the inside of the pipe in the ruptured area (Figures 9 and 10). Striations characteristic for microbiological corrosion were observed in these pits. A pit profile showed that chloride concentration in the pits increased steadily from the top to the bottom. Increased concentrations of chloride can be caused by some kind of microbial activity. All four types of microbes (sulfate reducing microbes that produce acid, aerobic and anaerobic) which may affect the corrosion process, were found in the samples collected from the pits in one piece from line 1103 with internal corrosion, discovered after the incident $630 \mathrm{~m}$ away from the place of explosion. Although the individual contribution of various microbes in the corrosion process could not be estimated, the damage morphology and the corrosion product analyses data suggest that microbiological activity contributed to the corrosion process (Nitin, nd).

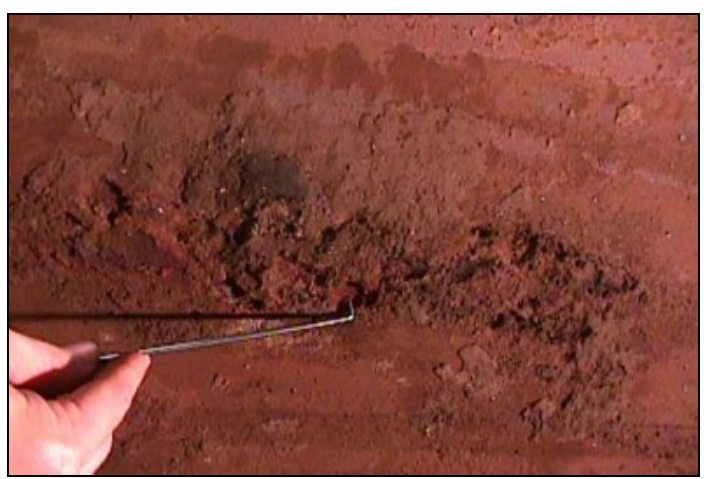

Figure 9 - Corrosion pitting on the inside of the pipe near the rupture site Puc. 9 - Питтинговая коррозия на внутренней стенке трубы в зоне разрыва Slika 9 - Piting korozija na unutrašnjoj strani cevi u zoni kidanja 
The El Paso Natural Gas Company (EPNG) committed itself to spend \$86 million on the replacement of 10,000 miles of the gas pipelines destroyed in the incident. Also, after this accident, the EPNG company developed a program to train staff on internal corrosion and implemented a program for integrity management which applies to 46,000 miles of the gas pipelines of the company. The EPNG identified 60 segments of the pipelines with the estimated risk of internal corrosion. These segments were inspected by non-destructive methods and internal corrosion was discovered on 8 pipelines. In the metallurgical laboratory of the company, on one of these lines, the experts found general internal corrosion which had reduced the thickness of the pipe wall for about $42 \%$ (https://abduh137.wordpress.com/2008/04/28/the-50-major-engineeringfailures-1977-2007-part-3).

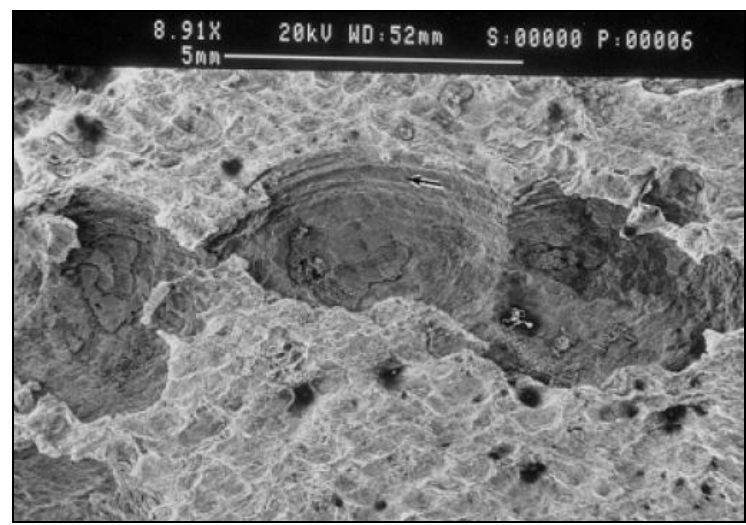

Figure 10 - Microscopic view of a corrosion pit in the Carlsbad pipeline Puc. 10 - Микрографическое изображение питтингов на трубопроводе в Карлсбаде Slika 10 - Mikrografski snimak korozivnog pita u cevovodu Carlsbad

\section{Guadalajara sewer explosions}

The explosions took place in Guadalajara on 22 April 1992, in the downtown district Analko. In a number of explosions of gas in the sewage system, 8 kilometers of streets were distroyed. Officially, by the Lloyd's of London accounting, 252 people were killed, nearly 1,500 were injured and 15,000 people were left homeless.

The sewer explosion was traced to the installation of the water pipe which had been placed above the gas installations several years before the explosion. The corrosion of the water pipes caused water leaks out of them, which subsequently caused the corrosion of the gas pipes and gas leaks in the sewers (Nitin, nd). 


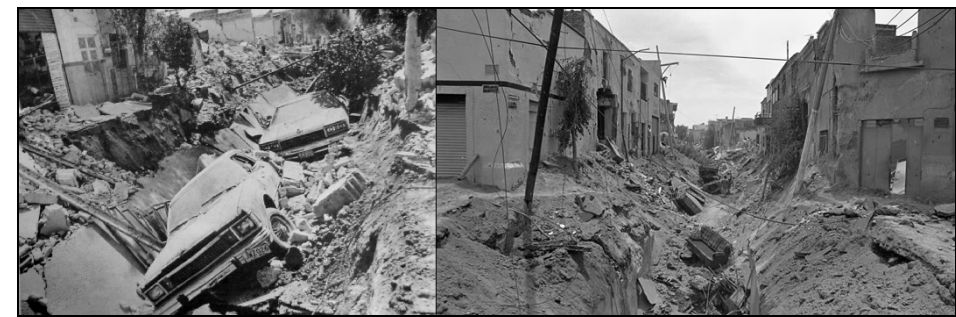

Figure 11 - Aftermath of the Guadalajara sewer explosions Puc. 11 - Последствия взрыва канализации в Гвадалахаре Slika 11 - Posledice eksplozije kanalizacije u Gvadalahari

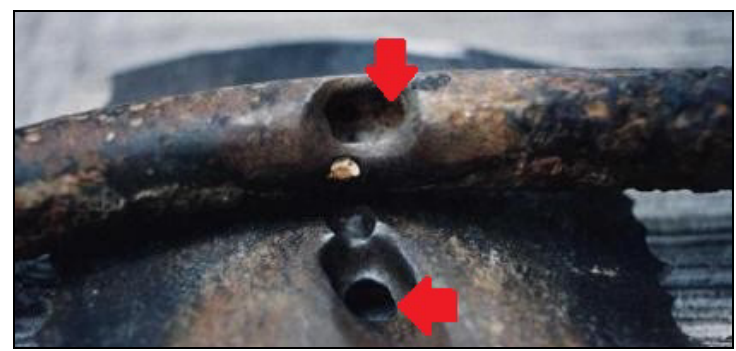

Figure 12 - Corrosion pits in the water pipelines

Puc. 12 - Коррозийные питтинги на трубе водопровода Slika 12 - Korozivni pitovi u vodovodnim cevima

\section{The explosion in the Gaylord Chemical Corporation}

On October 23 1995, at 15:55, at the Gaylord Chemical Corporation factory in Bagalusi, in Louisiana, there was a leak of yellow-brown steam out of the dome of the tank railway wagon. The tank contained a mixture of water and nitrogen tetroxide which is very toxic and corrosive. The initially formed "mushroom" of vapor had a diameter of 3-4 m. The staff of the factory notified the agency for emergency response and started the spraying of vapor by water from fire protection systems. Around 16:30 a fire crew arrived at the factory.

At 16.45 , damage occured to the rear of the tank wagon, resulting in breaking of a part of the tank jacket and its rejection at about $350 \mathrm{~m}$. At the same time, the tank wagon started to move, and after a $35 \mathrm{~m}$ ride, it derailed. A large red-brown cloud of steam was released from the tank. Vapors proceeded to go out through the hole in the tank wagon for the next 36 hours, until the chemical reaction was not put under control. Out of 4,710 people admitted to local hospitals, 81 were kept for treatment (http://www.corrosion-doctors.org/Process/ndustry/Bogalusa-explosion.htm).

Prior to the accident on 12 October 1995, nitrogen tetroxide was decanted from the rail tank to a storage tank. While this transfer was taking place, the material from the storage tank was simultaneously 
being transferred into the plant. At 09:00, the security system switched off the chemical reactor. The internal investigation into the cause of the security interruption of work of the chemical reactor revealed that nitrogen tetroxide had been contaminated by water. In order to prevent corrosion damage caused by the action of nitric acid, formed in the reaction of water with nitrogen tetroxide, the Gaylord management had decided to relocate the contaminated material from the tank wagon and the storage tank into the stainless steel cargo tank.

Overnight, between October 12 and 13, 1995, the measuring instrument showed that about 38,200 liters of the product were transferred from the storage tank into two cargo tanks. No other check was made on the storage tank or the cargo tanks to determine how much material had been transferred. When the transfer operation was finished, a material sample was taken from the transfer system. The sample contained a small amount of green liquid and foam. At 4:00 on 13 October, believing that the tank wagon was empty, factory employees poured water into it to dilute a what was believed to be - small amount of residual material that had remained in the tank to push it along the transfering pipe. Measurements after the accident showed that only 1,900 liters of material had been transferred into the cargo tanks, while the testing of the tank wagon after the accident showed that the transfering pipes were corroded and that only a small portion of each pipe near the top of the tank remained intact.

On October 19, the material samples obtained from the tank wagon and the three cargo tanks were taken to the Vicksburg Chemical Company for a chemical analysis. On October 20, the Gaylord employees began the transfer of the remaining material from the tank wagon, and by 18:00 that day, the mesuring instrument indicated that 25,400 liters of the material had been transferred from the tank wagon to the cargo tank. At the end of the transfer, the sample of material taken from the transfer system showed the presence of a small amount of foam and green liquid. Measuring of the material transferred into the the cargo tank, conducted after the accident, revealed that only about 3,200 liters of the material had been transferred.

Water for cleaning and washing the tank wagon was poured into it with a fire hose. Adding water was stopped when the pressure in the tank wagon reached a value of 4-4.5 bar. Gaylord employees vented out steam and reduced the pressure in the tank. Later, in the evening of 20 October, the staff in charge started emptying the tank wagon into the factory sewage system. After 2 or 3 minutes, a large vapor cloud was released, and the unloading was stopped. On 21 October, the workers added water twice in order to dilute the material in the tank wagon and they vented the tank. Every addition of water resulted in an increase of pressure in the tank.

On October 23, the measuring instrument on the tank wagon showed that the internal pressure was 1.24 bar. At 12:54 p.m., the Gaylord company received the results of the chemical analysis of the material sample obtained from the tank wagon on October 19. The results indicated that the material 
was nitrogen tetroxide. These results were unexpected because it was believed that on October 13 nitrogen tetroxide had been unloaded from the tank wagon and that the minimum residue had been diluted with water. The Gaylord staff concluded that there was an error in the Vicksburg Chemical Company during the chemical analysis and that the analyzed sample had not been the one taken from the material from the tank wagon.

Between 13:30 and 13:45 On October 23, the workers add more water into the tank wagon, and in 4-5 minutes the internal pressure increased from 1.2 bar to 5.5 bar, after which pouring water was stopped. Around 14:00, the pressure reached a value of 6.3 bar and began to decline slowly. At 14:30, the internal tank pressure was 3.8 bar. When one of the workers reused a fire hose and started pouring water again, the pressure increased to 7 bar, which was the maximum value of the measuring instrument. Water was turned off and the vapors were again vented. At 15:00, it seemed that the pressure was decreasing. However, at 15:30, the pressure was still over the limit and it began to rise again. At 15:55, yellow-brown vapor was observed leaking from the dome of the tank wagon. At 16:45, damage occurred to the rear of the tank wagon, resulting in the release of a huge red-brown vapor cloud. The examination conducted after the accident revealed a corroded opening $20 \mathrm{~cm}$ high and $170 \mathrm{~cm}$ wide at the head of the rear of the tank wagon, near the top of the tank. In addition, at least three distinctive horizontal bands of corrosion were found near the top of the interior tank wall, whereby one band was at the same level as the opening in the tank head (http://www.corrosion-doctors.org/ ProcessIndustry/Bogalusa-explosion.htm).

\section{Conclusion}

Although the mankind made remarkable progress in the last century, there have been cases stemming from this development and leading to losses of human lives. Corrosion in itself is not important, but the consequences of corrosion failure may be very serious. This paper presents the events in which corrosion was responsible for the loss of human lives. The investigations showed that the described disasters were the result of a combination of legal, technological, organizational and human errors. It has also been shown how much control and prevention of corrosion are important in order to prevent both financial losses and losses of human lives.

\section{References}

Findlay, S.J., Harrison, N.D., 2002, Why aircraft fail, Materials Today, Elsevier.

Komorowski, J.P., et al., 1996, Quantification of Corrosion in Aircraft Structures with Double Pass Retroreflection, Canadian Aeronautics and Space Journal, Vol.42, No.2.

Miller, D., 1990, Corrosion Control Aging Aircraft: What is being done?, Materials Performance. 
National Transportation Safety Board, 2003. Natural Gas Pipeline Rupture and Fire Near Carlsbad, New Mexico, August 19, 2000. Pipeline Accident Report NTSB/PAR03/01. Washington, D.C.

Nitin, S., Case study of some of the major corrosion catastrophes in the histiry, A report submitted at completion of the course on corrosion \& environmental degradation of materials (MT41013).

Wanhill. R., 2009, Istraživanje u Nacionalnoj vazduhoplovnoj laboratoriji (NLR) značajnih eksploatacijskih otkaza vazduhoplova, Integritet i vek konstrukcija, 9(2).

Wildey, J.F., 1990, Aging Aircraft", Materials Performance.

http://www.corrosion-doctors.org/Aircraft/Aloha.htm.

http://www.corrosion-doctors.org/Aircraft/el-al.htm.

http://www.corrosion-doctors.org/Pollution/bhopal.htm.

http://www.nace.org/CORROSION-FAILURES-EI-Paso-Natural-Gas-PipelineExplosion.aspx.

https://abduh137.wordpress.com/2008/04/28/the-50-major-engineering-failures1977-2007-part-3/.

\section{КАТАСТРОФЫ В РЕЗУЛЬТАТЕ ВОЗНИКНОВЕНИЯ КОРРОЗИИ}

Зоран Ц. Петрович

Вооруженные силы Республики Сербия, РВ ПВО,

204-ая военно-воздушная бригада, Батайница, Республика Сербия

ОБЛАСТЬ: материали, химические технологии

ВИД СТАТЬИ: обзорная статья

ЯЗЫК СТАТЬИ: английский

Резюме:

Проблема разрушения металлических материалов вследсдтвие возникновения коррозии привлекает большое внимание уже долаие годы. Опыт показал, что отказы инженерных сетей в результате воздействия коррозии являются важной проблемой, а согласно статистике мирового уровня выявлено, что ущерб от воздействия коррозии в промышленно развитых странах составляет 4-5\% национального дохода. B связи $c$ данной проблемой, на годовом уровне выделяются средства на предупреждение и контроль коррозийного воздействия. Игнорирование опасности от коррозии влечет за собой финансовые потери, а в отдельных случаях и человеческие жертвы.

В данной работе представлено несколько случаев маситабных отказов инженерных сетей и установок вследствие коррозийного воздействия, которые унесли сотни человеческих жизней.

Ключевые слова: катастрофра, отказ, коррозия, очаг коррозии, пестицид, взрыв, трубопровод, вертолет, самолет. 


\section{KATASTROFE IZAZVANE KOROZIJOM}

Zoran C. Petrović

Vojska Srbije, RV i PVO, 204. vazduhoplovna brigada, Batajnica,

Republika Srbija

OBLAST: materijali, hemijske tehnologije

VRSTA ČLANKA: pregledni članak

JEZIK ČLANKA: engleski

\section{Sažetak:}

Problemu korozivnog oštećenja i razaranja metalnih materijala već godinama se posvećuje velika pažnja. Svetska statistika pokazuje da je šteta koja nastaje usled delovanja različitih oblika korozije ogromna i da, na primer, u industrijski razvijenim zemljama dostiže 4 do 5\% nacionalnog dohotka. Za prevenciju i kontrolu korozije izdvajaju se znatna sredstva na godišnjem nivou. U slučaju ignorisanja problema korozije izriču se finansijske kazne, a može doći i do katastrofalnih posledica - gubitka ljudskih života.

U ovom članku predstavljeno je nekoliko slučajeva otkaza inženjerskih struktura i postrojenja katastrofalnih razmera, u kojima je korozija odgovorna za pojavu otkaza i pogibiju stotine ljudi.

Ključne reči: katastrofa, otkaz, korozija, korozivni pit, pesticid, eksplozija, cevovod, helikopter, avion.

Paper received on / Дата получения работы / Datum prijema članka: 28. 02. 2016.

Manuscript corrections submitted on / Дата получения исправленной версии работы / Datum dostavljanja ispravki rukopisa: 03. 04. 2016.

Paper accepted for publishing on / Дата окончательного согласования работы / Datum konačnog prihvatanja članka za objavljivanje: 05. 04. 2016.

(C) 2016 The Author. Published by Vojnotehnički glasnik / Military Technical Courier (www.vtg.mod.gov.rs, втг.мо.упр.срб). This article is an open access article distributed under the terms and conditions of the Creative Commons Attribution license (http://creativecommons.org/licenses/by/3.0/rs/).

() 2016 Автор. Опубликовано в "Военно-технический вестник / Vojnotehnički glasnik / Military Technical Courier" (www.vtg.mod.gov.rs, втг.мо.упр.срб). Данная статья в открытом доступе и распространяется в соответствии с лицензией "Creative Commons" (http://creativecommons.org/licenses/by/3.0/rs/).

(c) 2016 Autor. Objavio Vojnotehnički glasnik / Military Technical Courier (www.vtg.mod.gov.rs, втг.мо.упр.срб). Ovo je članak otvorenog pristupa i distribuira se u skladu sa Creative Commons licencom (http://creativecommons.org/licenses/by/3.0/rs/).

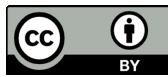

